Jurnal Spektrum Komunikasi Vol. 9 No. 2 Desember 2021

\title{
Data Journalist : One Data Indonesia (SDI) Weak of Data
}

\author{
Maulana Arief1, Amalia Nurul Muthmainnah² \\ Communication Sceince, FISIP, 17 Agustus 1945 Surabaya University \\ maulanaarief@untag-sby.ac.id
}

\begin{abstract}
Indonesia government built Satu Data Indonesia (SDI) as part of implementing the principle of open government. Through SDI, all data from Indonesia government, including data from local government and government agencies can be easily accessed by visiting the data.go.id website.This situation should be a good ecosystem to develop data journalism in Indonesia, because government provides abundant data. This study aims to see the implementation of SDI from the perspective of data journalists. Data journalist is a profession that related to SD directly, they are tasked with managing data to be presented to the public in a simple and easy-to-understand manner for the general public. By interviewing data journalists from Katadata and Lokadata (two online media who declare themselves as data journalism), this qualitative research is expected to provide constructive input on the implementation of Satu DataIndonesia. In general, the existence of SDI is appreciated by data journalists. But data journalists from Katadata and Lokadata do not use SDI as part of their news-seeking activities. They see SDI has basic problems, the lack of data availability, data relevance problems, problems with data access, no data updates and problem with data reliability. On the other hand, not all regions in Indonesia are connected to SDI. As a result, data journalists do not use Satu Data Indonesia as an instrument to produce news. They prefer to dig up data through data mining on the internet independently and collect data gradually in their data bank for processing a news.
\end{abstract}

Keywords: One Data Indonesia, Open Government, Online Media, Data Journalism

\begin{abstract}
ABSTRAK
Pemerintah membangun satu data Indonesia (SDI) sebagai bagian dari menjalankan prinsip open government. Melalui SDI, semua data dari pemerintah dari daerah hingga pusat termasuk data dari lembaga pemerintahan dapat dengan mudah diakses dengan berkunjung pada website data.go.id. Situasi ini harusnya menjadi ekosistem yang bagus dalam perkembangan jurnalisme data di Indonesia, karena pemerintah menyediakan data yang melimpah. Penelitian ini, bertujuan untuk melihat implementasi SDI dari kacamata (persepsi) jurnalis data. Karena jurnalis data adalah profesi yang berkatian langsung dengan SDI, mereka bertugas megelola data untuk disampaikan pada publik secara sederhana dan mudah dipahami masyarakat awam. Dengan mewawancarai para
\end{abstract}

ISSN 2338 - 0861 (cetak); e-ISSN 2621 - 8712 (online)

website : http://spektrum.stikosa-aws.ac.id 
jurnalis data dari Katadata dan Lokadata (dua media online yang mendeklarasikan diri sebagai media yang mengembangkan jurnalisme data), penelitian kualitatif ini diharapkan dapat memberikan masukan kontruktif pada pelaksanaan Satu Data Indonesia. Secara umun, keberadaan SDI diapresiasi oleh jurnalis data, namun, jurnalis data dari katadata dan Lokadata justru tidak menggunakan SDI sebagai bagian dari aktifitas mencari berita. Mereka melihat SDI memiliki permasalahan mendasar yaitu minimnya ketersediaan data, masalah relevansi data, persoalan kemudahan akses data, tidak ada keterbaruan data (update) hingga keandalan data. Selain itu SDI dinilai memiliki masalah pada upadate data dan keandalan data, disisi lain tidak semua daerah di Indonesia terkoneksi dengan SDI. Akhibatnya, jurnalis data tidak menjadikan Satu Data Indonesia sebagai intrumen membuat berita. Mereka lebih memilih menggali data melalui mining data di internet dan mengumpulkan data secara bertahap pada bank data mereka untuk diolah pada kemudian hari.

Kata-kata Kunci : Satu Data Indonesia, Open Government, Media Online, Jurnalisme Data

\section{Introduction}

Government openness to information (data) is very vital for the development of data journalism because implementation of data journalism depends a lot on government information disclosure (Roza, 2019). The more government provides of data, the greater the opportunity for data journalists to process and analyze of news to be presented to the public. In Indonesia, data disclosure is an important issue. Its implementation has received a lot of pressure from various groups, including journalists UurnalismeData - Berita - Tentang Kami, n.d.).

In mid-2019, the president issued regulation perpres No. 39 year of 2019, concerning of One Data Indonesia / Satu Data Indonesia (SDI). The Presidential Regulation is guarantee open data of government must meet elements of being accurate, up-to-date, integrated, accountable, easily accessible, and easy to share (Humas Setkab, 2019). Implementation of the regulation, Indonesia government builds a web data portal (data.go.id). The Satu Data Indonesia Portal is the official of Indonesia open data portal, managed by Satu data Indonesia Secretariat at Ministry of National Development Planning (BAPENNAS).

Through the portal data provider, public can access all data and statistical along with metadata, ranging from access to data from local to central government, including data from state institutions to ministries.

One Data Indonesia cannot be separated from the government's commitment for implementing of open government, a consequence of joining the Open Government Partnership. A global issue for the democratization of state administration. One of the programs is the availability of data in a transparent, participatory and accountable manner (Marković \& Gostojić, 2020). This joint commitment program is carried out by 78 countries in the world, including Indonesia.

SDI and Data Journalism actually have the same task, they have to convey reliable data to the public. Public need data as part of their decision making in their daily life. However, as a bridge (media) to the audience, data journalists rely on the availability of data

ISSN 2338 - 0861 (cetak); e-ISSN 2621 - 8712 (online)

website : http://spektrum.stikosa-aws.ac.id 
from the government. Through SDI, journalists can dig up data with one visit to the website available at data.go.id. In December 2020, SDI Portal (data.go.id) is connected to 43 agency data portals, with a total dataset of 41,708 and accumulated 58,155 (Islami, 2021). Through that data, journalists hope to find a variety of important and interesting data to enrich their journalistic work, including developing investigative journalism (Irham, 2017).

According to Open government partnership, journalists are an important instrument in the development of data openness. Without journalists, open government is weakened. Journalists function as critical intermediaries, connecting public institutions, decision makers and the public. Through the news that is delivered, it can increase public awareness and demand accountability (Global Report: Defending Activists and Journalists, 2019).

That's why the Alliance of Independent Journalists (AJI) actively encourages its members to expand their coverage by conducting training on the use of scattered data on a number of government sites, research institutions, and NGOs (Irham, 2017). Data Journalism works by digging up various documents and data scattered from various sources, mainly from the internet. Through certain software, hundreds or thousands of documents are linked to one another. The complex data, then display it in an infographic (Gray et al., 2012), The goal is to make it easier for readers to understand (Roza, 2019). It is an collaborative work between data analysts and designers who are not in the realm of journalism (Roza, 2019), that collaborative makes the different between data journalism and conventional journalism.

The availability of data is the most basic need for the Data Journalism ecosystem. With the
Satu Data Indonesia program, data journalists (journalists who work in data journalism) are expected to be able to use the data.go.id website in their journalistic work. However, this needs to be looked at more deeply, whether data journalists use data.go.id in producing news, can journalists rely on the data in SDI?

So far, there have been several studies on data journalism in Indonesia. For example, Innovation of Data Journalism in online media in Indonesia (Badri, 2017), Trends and Phenomenon of Data Journalism in Online Media in Indonesia (Widiantara, 2021), Data Journalism in Digitizing Tempo's Investigative Journalism (Asprilla \& Maharani, 2019), The Meaning of Data Journalism for Today's Journalists (Puteri \& Gani, 2018), Structural Problem in the Practice of Data Journalism in Indonesia Case studies at Katadata.co.id, Tirto.id and Beritagar.id (Dimas Jarot Bayu, 2019), and research about Data Journalism Application at Katadata (Walfajri, 2017).

From all the research, it seems there has been no study from a journalist's point of view on the implementation of Satu Data Indonesi (SDI). Whereas SDI can be the most crucial data source for the development of data journalism in Indonesia. A study states that Open Data Indonesia is still at the first level in the open stage model, meaning that the government is not serious about the issue of open data (Gunawan \& Amalia, 2017). In research, Gunawan \& Amalia (2017), measuring the level of openness and implementation of SDI using the open-stage model. Other research states that the implementation of SDI encounters several obstacles, including difficulties in integrating data because the data is not standardized or metadata is not uniform (Islami, 2021).

From the research above, it seems that the implementation of SDI is not optimal yet.

ISSN 2338 - 0861 (cetak); e-ISSN 2621 - 8712 (online)

website : http://spektrum.stikosa-aws.ac.id 
However, research related to the implementation of SDI, so far has not seen from the point of view of a Data Journalist, a profession that requires data in its work process. This research is expected to provide a different point of view, from the point of view of data journalists as users of government data. Through in-depth interviews, the research will investigate journalists' perceptions of the implementation of SDI ? Including to see whether data journalists use SDI in their journalistic work.

\section{METHODS}

This study is a descriptive qualitative research by conducting in-depth interviews with data journalists in Indonesia. Interviews will be conducted on online media journalists from katadata.id and lokadata.id. Both are media that proclaim themselves as media who develop data journalism in Indonesia. Each representative of the media was represented by five people from the editorial crew, such as representatives of journalists, data analysts and editors. Informants were interviewed separately in order to express their perception of SDI implementation (data.go.id).

\section{RESULT AND DISCUSSION}

Since the issuance of presidential regulation number 39 year of 2019, the Satu Data Indonesia (SDI) program were expected to provide information that can be used by the public, including journalists. Data journalists from katadata.id and lokadata.id appreciate the existence of data.go.id as the implementation of One Data Indonesia. By the basic principle of data openness, it is hoped that SDI can support their work in producing news. When compared to the previous 5 to 10 years, the presence of SDI is considered to be much better than none at all.
However, there are several things that need to be considered at the level of data implementation at the One Data Indonesia program. Journalists feel that the data availability on the data.go.id portal is very minimal. Eventhough, visiting data.go.id journalist can cut 43 data portals belonging to government agencies (Islami, 2021). However, the lack of data availability is still felt by journalists because not all types of data are available. SDI only provide data with important indicators, such as global poverty data, GRDP data (Gross Regional Domestic Product) which has been used as government reports. Apart from this data, there are many other data that have not been disclosed. For example, related to social issues, it is still not widely available.

Data journalism requires a lot of data to be selected, verified, analyzed and synthesized (Gray et al., 2012, p.9), the accumulation of 58,155 files (Islami, 2021), may be considered very minimal for data journalists. Apart from the lack of data availability, there are also issues related to the relevance of the available data. Journalists still have to recheck the date the data was issued and the completeness of the available data, whether it is still relevant to use or not. This was predicted by Kalatzi et all (2018), one of the main problems is the data published by the governments, other governmental bodies and organizations. Many of the datasets are not published soon enough for the journalists to use them for a news story. For instance, when a journalist starts an investigation the data available usually is up to two years old, which has no value in a journalistic sense (Kalatzi et al., 2018). This phenomenon also occurs in SDI.

SDI Portal (data.go.id), is considered not to update data properly. The data journalists admitted that they often monitored the data portal from Satu Data Indonesia, at the beginning of the program. However, minimal

ISSN 2338 - 0861 (cetak); e-ISSN 2621 - 8712 (online)

website : http://spektrum.stikosa-aws.ac.id 
use of the data contained in it as an instrument for making news because it does not find updated data (data update).

This doesn't update the data, we rarely take it from here, then there's a lot of missing information, sometimes there's no reference. Then there is no explanation, there are many who miss here, I can even say that $50 \%$ we can use, the rest we need to study again. (Agus Dwi Darmawan, Katadata Data Manager, Interview, 23 September 2021)

This statement shows that data journalists doubt the veracity of the data available in One Data Indonesia. They have to do further research when retrieving data from data.go.id, or even don't hesitate to leave SDI data. This is because the basic principle of data journalism requires data reliability. Even in practice, data journalists have to spend a lot of time rechecking data integrity, repeatedly checking data from competent authorities (government) (Gray et al., 2012, p.66).

Katadata and lokadata journalists are also see that the available data is not easy to read, because the data format is not standardized. Journalists need data that is easy to obtain (download) with easy-to-read data content. They hope that data.go.id can imitate the implementation of open data abroad such as the UK which has data.gov.uk, data that is always updated, easily accessible and downloadable. The datasets on data.go.uk are often in comma-separated value (CSV) format or spreadsheets, but there is potential for increasing their utility by linking them using structured machine-processable formats. Resource Description Framework (RDF) is the format most integrated into current thinking about future generations of the Web, as its use of URIs allows data to be identified by reference and linked with other relevant data by subject, predicate, or ob- ject
(Shadbolt et al., 2012). SDI is considered to have minimal use of data in RDF format, as a result all available data cannot be linked to other data sources (Gunawan \& Amalia, 2017).

Actually, the government has tried to improve it by issuing Presidential Regulation number 39 of 2019, which orders data to be standardized, data must have metadata, data must meet interoperability rules, and data produced by Data Producers must use reference codes and/or Master Data (Humas Setkab, 2019). However, data journalists are still reluctant to use SDI because of the lack of available data, problems with data relevance, problems with easy data access, no data updates (updates) and the available data is not reliable.

One data Indonesia (data.go.id) works by collecting all data (web portal data) from local and central governments to government-owned agencies, as well as ministerial institutions. Thus, all government data and other related agency data lead to SDI. However, data journalists see that not all government data is open, especially data from local governments. The indicator is that there is still a lot of data that is not yet available, for example data on social issues and crime.

Data Journalists are also admit that all regions cannot be generalized (not having the readiness to submit data). There are several regions that are considered very good at providing data, for example Bojonegoro district for the East Java region, and the Bandung and Garut regional governments for the West Java region (Andrea Lidwina, katadata journalist, interview 29 September 2021). But, in general there are still many local governments that have not disclosed their data so that the single data portal has not been utilized properly. Whereas data availability and data accountability are indicators of open government (Marković \& Gostojić, 2020).

ISSN 2338 - 0861 (cetak); e-ISSN 2621 - 8712 (online)

website : http://spektrum.stikosa-aws.ac.id 
In a report, Warta Satu Data Indonesia stated that the main problem in implementing One Data Indonesia (SDI) was the absence of technical/implementation instructions regarding data formats and metadata. In addition, it is necessary to integrate data lists through local government information systems and develop skills sets that support geospatial data (Andrianto, 2021).

The issue of readiness of data providers at the local level seems to be the reason not all data is available. However, Lokadata journalist Nanang Syaifudin (interview, August 16, 2021) sees that there is an element of sectoral ego that causes not all data to be released and connected to SDI. On the other hand, each region has an open data website with different data formats, so further work is needed to read the data.

Data from the government is the main supply for Data Journalists in writing news. Although there is already a data access facility through Satu Data Indonesia, due to the problems above, journalists from Katadata and Lokadata are selectively hunting for the required data by visiting data portals spread throughout Indonesia.

They work to collect data that is considered important (regular government reports), then stored in the data bank they have. Another option is to do data mining scattered on the internet. This is done because Data Journalism works with very large data to be shared with various newsrooms (Hidayat \& Hidayat, 2020).

In practice, in digging up data from the government, Katadata and Lokadata journalists have to take the required data one by one, by accessing the websites of government institutions or hunting for periodic reports. For example, if you are looking for data on population data, you will look at several different institutions (which have the authority) such as the Ministry of Home Affairs, the Population and Civil Registration Service, and the Central Statistics Agency (BPS).

The risk for journalist to search government data separately is getting data that varies from one another. An example of a case is the Covid-19 death rate data, Annissa Mutia Editor of Katadata (interview, September 16, 2021) revealed that the data issued by the central government and regional governments are different. The phenomenon of asynchronous data between government agencies also occurs in institutions that are authorized to cover the same scope.

Often find data differences from one agency to another. For example, the number of villages according to the BPS version and the number of villages according to the Ministry of Home Affairs is different. It's between institutions. Between agencies in the Ministry of Home Affairs is also different. So, the number of villages is different. You can imagine why the One Data Indonesia (SDI) has not yet happened even though it was inaugurated in 2017. (Agung Setyo Nugroho, Head of Data Logistics Division, Lokadata, interview 16, August 2021)

To the difference of data, journalists respond in several ways. First, is to display the data, only from the agency that has the authority from the data. The second way is to investigate further which data is closer to the truth. Data verification is carried out strictly by looking at the raw data especially regarding date and year updates and comparing with each other, the data makes sense which is then served. The third way is

ISSN 2338 - 0861 (cetak); e-ISSN 2621 - 8712 (online)

website : http://spektrum.stikosa-aws.ac.id 
to display all of the differences in the data. The difference in the data will be reported, the writing will be honest about the difference in the data. The fourth method is to collect data from independent institutions and foreign institutions that are more trusted. of course, this concerns special issues recorded by foreign/independent institutions such as the World Bank, IMF, worddometer.info, ourworldinData.org, datatalk.asia and so on. All these ways, of course, are not sequential steps. In the field, journalists will choose one or more method that is most appropriate to the justification (assessment) of the journalists covering.

One of the impacts of the era of information disruption, citizens have the potential to be confused by the abundance of data scattered on the Internet. One of the impacts of the era of information disruption, citizens have the potential to be confused by the abundance of data scattered on the Internet, and even trapped by the issue of hoaxes. Because of this, the mass media that carry the dignity of journalism and strict verification are relevant (Surya Abadi, 2019).

With the ability to rigorously verify data, journalists can find data online and they can

\section{BIBLIOGRAPHY}

Andrianto, G. (2021). Warta Satu Data Indonesia-BAPPENAS. BULETIN EDISI II April-Juni 2021, 17-18.

Asprilla, A., \& Maharani, N. (2019). Jurnalisme Data Dalam Digitalisasi Jurnalisme Investigasi Tempo. Jurnal Kajian Jurnalisme, 2(2), 212-224. https://doi.org/10.24198/jkj.v2i2.2136 2

Badri, M. (2017). Inovasi Jurnalisme Data use a vast majority of tools and programs to clean them, analyze them and create the right visualizations. (Kalatzi et al., 2018). It is undeniable that the data that journalists use the most is data sourced from the government. When compared to central and local government agencies, ministries and institutions as part of the implementation of One Data Indonesia, data journalists rely more on data from BPS as the basic material for managing information.

\section{CONCLUSION}

The implementation of One Data Indonesia (SDI) has not been able to answer the needs of data journalists in managing information (data) to be conveyed to the public. This is due to the lack of available data, data relevance problems, problems with ease of data access, no data updates (updates) and the available data is not reliable. So that data journalists do not use SDI as an important instrument in processing data. In the spirit of data openness, data journalists appreciate the existence of SDI. However, the SDI Secretariat from the Ministry of BAPPENAS is expected to be able to solve the basic problems mentioned above so that the data available in SDI can be used by the public.

Media Online di Indonesia. Tren Pola Komunikasi Media Di Indonesia Tahun 2017, October 2017, 356.

Dimas Jarot Bayu, author. (2019). Persoalan Struktural dalam Praktik Jurnalisme Data di Indonesia (Studi Kasus pada Katadata.co.id, Tirto.id, dan Beritagar.id) = Structural Problems in Application of Data Journalism in Indonesia (Case Study of Katadata.co.id, Tirto.id, and Beritagar.id). http://lib.ui.ac.id

Global Report: Defending Activists and Journalists. (2019). Open Government Partnership. https://www.opengovpartnership.org/d ocuments/global-report-defending-

ISSN 2338 - 0861 (cetak); e-ISSN 2621 - 8712 (online)

website : http://spektrum.stikosa-aws.ac.id 
activists-and-journalists /

Gray, J., Bounegru, L., \& Chambers, L. (2012). The Data Journalism Handbook (S. Wallace (Ed.); Firts Edit, Vol. 1). O'reilly Media, Inc.

Gunawan, D., \& Amalia, A. (2017). The Implementation of open data in Indonesia. Proceedings of 2016 International Conference on Data and Software Engineering, ICoDSE 2016, October. https://doi.org/10.1109/ICODSE.2016.7 936164

Hidayat, Z., \& Hidayat, D. (2020). Data-driven journalism based on big data analytics: A model development from Indonesia's experience. Journal of Content, Community and Communication, 10(6), 65-83.

https://doi.org/10.31620/JCCC.06.20/0 6

Humas Setkab. (2019). Presiden Jokowi Tanda Tangani Perpres No. 39/2019 tentang Satu Data Indonesia. Sekretariat Kabinet Republik Indonesia. https://setkab.go.id/presiden-jokowitandangani-perpres-no-392019tentang-satu-data-indonesia/

Irham, M. (2017). Jurnalisme Data Mendorong Pemerintahan yang Transparan. https://independen.id/read/media/290 /jurnalisme-data-mendorongpemerintahan-yang-transparan

Islami, M. J. (2021). Implementasi Satu Data Indonesia: Tantangan dan $<\mathrm{em}>$ Critical Success Factors $</$ em $>$ (CSFs). Jurnal Komunika: Jurnal Komunikasi, Media Dan Informatika, 10(1), 13. https://doi.org/10.31504/komunika.v1 $0 \mathrm{i} 1.3750$

JurnalismeData - Berita - Tentang Kami. (n.d.). Retrieved November 18, 2021, from https://jurnalismedata.id/page/tentang -kami

Kalatzi, O., Bratsas, C., \& Veglis, A. (2018). The Principles, Features and Techniques of Data Journalism. Studies in Media and Communication, 6(2), 36.

https://doi.org/10.11114/smc.v6i2.320 8

Marković, M., \& Gostojić, S. (2020). Open Judicial Data: A Comparative Analysis. Social Science Computer Review, 38(3), 295-314.

https://doi.org/10.1177/08944393187 70744

Puteri, F. R. K., \& Gani, R. (2018). Makna Jurnalisme Data Bagi Jurnalis Masa Kini. Prosiding Jurnalistik: Seminar Penelitian Sivitas Akademika Unisba, 4(1), 24-30.

Roza, A. M. (2019). Perkembangan Teknologi Informasi dan Jurnalisme. Jurnal Dewan Pers, 20(November), 4-68. https://dewanpers.or.id/publikasi/publ ikasi_detail/241/Perkembangan_Teknol ogi_Informasi_dan_Jurnalisme

Shadbolt, N., O'Hara, K., Berners-Lee, T., Gibbins, N., Glaser, H., Hall, W., \& Schraefel, M. C. (2012). Open Government Data and the Linked Data Web: Lessons from data. gov. uk. IEEE Intelligent Systems, 27(3), 16-24. http://eprints.soton.ac.uk/340564/ Surya Abadi, H. (2019). Media Sosial dan Antitesis Jurnalisme. Jurnal Spektrum Komunikasi, 7(1), 17-29. https://doi.org/10.37826/spektrum.v7i 1.26

Walfajri, M. (2017). PENERAPAN JURNALISME DATA DI KATADATA. http://repository.unpad.ac.id/frontdoor /index/index/docId/32929

Widiantara, I. K. A. (2021). Tren Dan Fenomena Jurnalisme Data Pada Media Online Di Indonesia. DANAPATI: Jurnal Komunikasi, 1(2), 118-125.

ISSN 2338 - 0861 (cetak); e-ISSN 2621 - 8712 (online)

website : http://spektrum.stikosa-aws.ac.id 